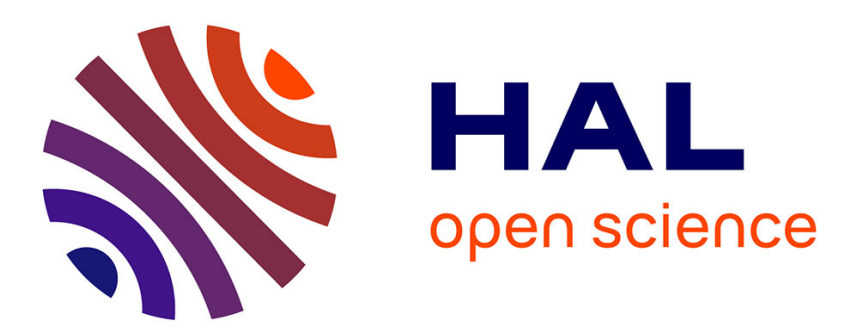

\title{
ICTV Virus Taxonomy Profile: Metaviridae
}

Carlos Llorens, Beatriz Soriano, Mart Krupovic, Ictv Report Consortium

\section{To cite this version:}

Carlos Llorens, Beatriz Soriano, Mart Krupovic, Ictv Report Consortium. ICTV Virus Taxonomy Profile: Metaviridae. Journal of General Virology, 2020, 101 (11), pp.1131 - 1132. 10.1099/jgv.0.001509 . pasteur-03112957

\section{HAL Id: pasteur-03112957 \\ https://hal-pasteur.archives-ouvertes.fr/pasteur-03112957}

Submitted on 18 Jan 2021

HAL is a multi-disciplinary open access archive for the deposit and dissemination of scientific research documents, whether they are published or not. The documents may come from teaching and research institutions in France or abroad, or from public or private research centers.
L'archive ouverte pluridisciplinaire HAL, est destinée au dépôt et à la diffusion de documents scientifiques de niveau recherche, publiés ou non, émanant des établissements d'enseignement et de recherche français ou étrangers, des laboratoires publics ou privés.

\section{(ㄷ)(1)}

Distributed under a Creative Commons Attribution| 4.0 International License 


\title{
ICTV Virus Taxonomy Profile: Metaviridae
}

\author{
Carlos Llorens ${ }^{1, *}$, Beatriz Soriano', Mart Krupovic ${ }^{2, *}$ and ICTV Report Consortium
}

\begin{abstract}
Metaviridae is a family of retrotransposons and reverse-transcribing viruses with long terminal repeats belonging to the order Ortervirales. Members of the genera Errantivirus and Metavirus include, respectively, Saccharomyces cerevisiae Ty3 virus and its Gypsy-like relatives in drosophilids. This is a summary of the International Committee on Taxonomy of Viruses (ICTV) Report on the family Metaviridae, which is available at ictv.global/report/metaviridae.
\end{abstract}

Table 1. Characteristics of members of the family Metaviridae

\begin{tabular}{|ll|}
\hline Typical member: & Saccharomyces cerevisiae Ty3 virus (M34549), species Saccharomyces cerevisiae Ty3 virus, genus Metavirus \\
\hline Virion & Virions are icosahedral (T=9) and might be enveloped \\
Genome & Two identical copies of linear single-stranded, positive-sense RNA \\
Replication & Replication by reverse-transcription primed with a host-encoded tRNA \\
Translation & Genomic RNA is translated into one or more polyproteins \\
Host range & Fungi, plants and animals \\
Taxonomy & Realm Riboviria, kingdom Pararnavirae, phylum Artverviricota, class Revtraviricetes, order Ortervirales, family Metaviridae; the \\
& genera Errantivirus and Metavirus include $>30$ species \\
\hline
\end{tabular}

\section{VIRION}

The morphology of virus-like particles (VLPs) is poorly characterized; a high-resolution structure is only available for Saccharomyces cerevisiae Ty3 virus (Table 1, Fig. 1). Saccharomyces cerevisiae Ty3 VLPs are icosahedral ( $T=9)$ and built from a capsid protein, which is homologous to the corresponding protein of retroviruses and other members of the order Ortervirales [1-3]. Most VLPs do not appear to be infectious extracellularly, although Drosophila melanogaster Gypsy virus does generate infective VLPs [4]. By analogy with members of the family Retroviridae, VLPs are thought to contain two copies of the viral RNA genome, complexed with the nucleocapsid protein, cellular tRNAs involved in the priming of reverse transcription, reverse transcriptase and integrase. Virions of Drosophila melanogaster Gypsy virus also contain the envelope glycoprotein responsible for recognition and binding of VLPs to host cells and fusion of the viral and cellular membranes [5].

\section{GENOME}

The genome of a canonical member of the Metaviridae has an internal region that may range from $3 \mathrm{~kb}$ to $>15 \mathrm{~kb}$ flanked by two homologous non-coding sequences called long terminal repeats (LTRs) (Fig. 2). A canonical LTR has three subregions, U3-R-U5, which are analogous to those of retroviruses. 'U3' (200-1200 nt) contains the promoters; ' $R$ ' is repeated on each end of the transcript; and 'U5' (75-250 nt) constitutes the first portion of the reverse-transcribed genome. The internal region is delimited by two small motifs: an $18 \mathrm{nt}$ sequence downstream of the $5^{\prime}$-LTR (the primer binding site, PBS) and about ten $A / G$ residues located upstream of the $3^{\prime}$-LTR (the

Received 16 September 2020; Accepted 22 September 2020; Published 13 October 2020

Author affiliations: 'Biotechvana, Scientific Park University of Valencia, 46980, Paterna, Valencia, Spain; ${ }^{2}$ Archaeal Virology Unit, Institut Pasteur, 75015

Paris, France.

*Correspondence: Carlos Llorens, carlos.llorens@biotechvana.com; Mart Krupovic, mart.krupovic@pasteur.fr

Keywords: Metaviridae; ICTV; taxononmy; retrotransposon.

Abbreviations: LTR, long terminal repeat; PBS, primer binding site; PPT, polypurine tract; VLP, virus-like particle.

001509 (c) 2020 The Authors 


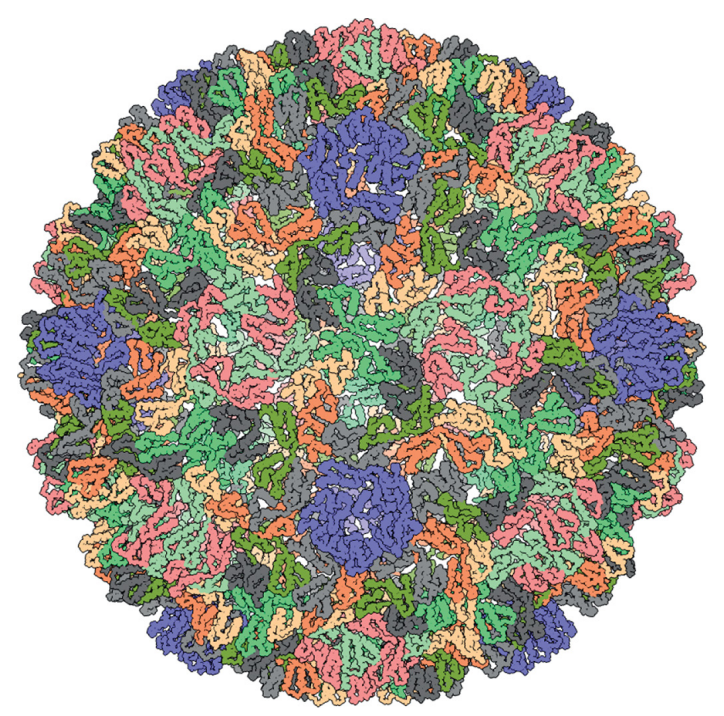

Fig. 1. Three-dimensional reconstruction of a VLP of Saccharomyces cerevisiae Ty3. Diameter about $47 \mathrm{~nm}$. PDB id: 6R24 [1].

polypurine tract, $\mathrm{PPT})$. The internal region may have one (gag-pol), two (gag and $p o l)$ or three (gag, pol and env) genes. The gag gene encodes domains for the capsid and the nucleocapsid proteins, whereas the pol gene includes domains for the protease, reverse transcriptase, ribonuclease $\mathrm{H}$ and integrase proteins. Where present, envelope (Env) polyproteins contain transmembrane and surface domains and are encoded downstream of the integrase domain $[6,7]$.

\section{REPLICATION}

Members of the family Metaviridae replicate via reverse transcription within intracellular VLPs. The cellular tRNA packaged in the VLP anneals to the RNA genome in the PBS region complementary to the $3^{\prime}$-end of that tRNA and is used by reverse transcriptase as an initiation primer. The proviral cDNA is imported into the nucleus, followed by integration into a chromosomal target site by the integrase.

\section{TAXONOMY}

Current taxonomy: ictv.global/taxonomy. The genera Errantivirus and Metavirus differ by the presence or absence of the env gene, respectively. However, this criterion is inconsistent with current knowledge of the evolutionary history of the family Metaviridae. While the genus Errantivirus constitutes a monophyletic clade, members of the genus Metavirus, form distinct clades showing polyphyletic relationships with each other. Furthermore, not all errantiviruses have env genes and, conversely, certain members of the genus Metavirus have env genes. A revision of the Metaviridae is required.
Saccharomyces cerevisiae Ty3 virus, 5.4 kb, genus Metavirus

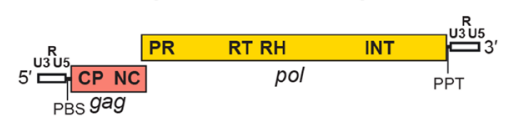

Drosophila melanogaster Gypsy virus, $7.5 \mathrm{~kb}$, genus Errantivirus

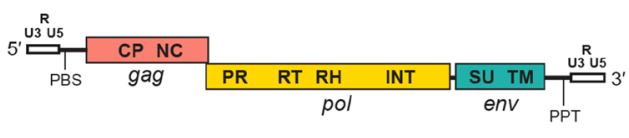

0

$5 \mathrm{~kb}$

$10 \mathrm{~kb}$

Fig. 2. Metavirus genome structure. LTRs (white) are labelled with the U3, R and U5 regions. Other labels are PBS (primer binding site), PPT (polypurine tract), gag (pink) with its capsid (CP) and nucleocapsid (NC) domains, pol (yellow) with its protease (PR), reverse transcriptase (RT), ribonuclease $\mathrm{H}(\mathrm{RH})$ and integrase (INT) domains, and env (blue-green) with its surface (SU) and transmembrane (TM) domains.

\section{RESOURCES}

Full ICTV Report on the family Metaviridae: ictv.global/ report/metaviridae

Gypsy Database (GyDB) devoted to viruses and mobile genetic elements: http://gydb.org

Funding information

Beatriz Soriano was supported by the pre-doctoral research fellowship from Industrial Doctorates of MINECO (Grant 659 DI-17-09134). Production of this Profile, the ICTV Report, and associated resources was funded by a grant from the Wellcome Trust (WT108418AIA).

\section{Acknowledgements}

Members of the ICTV Report Consortium are Stuart G. Siddell, Andrew J. Davison, Elliot J. Lefkowitz, Sead Sabanadzovic, Peter Simmonds, Donald B. Smith, Richard J. Orton and Balázs Harrach.

Conflicts of interest

The authors declare that there are no conflicts of interest

\section{References}

1. Dodonova SO, Prinz S, Bilanchone V, Sandmeyer S, Briggs JAG Structure of the Ty3/Gypsy retrotransposon capsid and the evolution of retroviruses. Proc Natl Acad Sci USA 2019;116:10048-10057.

2. Krupovic M, Koonin EV. Homologous capsid proteins testify to the common ancestry of retroviruses, caulimoviruses, pseudoviruses, and metaviruses. J Virol 2017:91:e00210-17.

3. Krupovic M, Blomberg J, Coffin JM, Dasgupta I, Fan H et al. Ortervirales: new virus order unifying five families of reverse-transcribing viruses. J Virol 2018;92:e00515-18.

4. Kim A, Terzian C, Santamaria P, Pélisson A, Purd'homme N et al. Retroviruses in invertebrates: the gypsy retrotransposon is apparently an infectious retrovirus of Drosophila melanogaster. Proc Natl Acad Sci USA 1994;91:1285-1289.

5. Song SU, Gerasimova T, Kurkulos M, Boeke JD, Corces VG. An envlike protein encoded by a Drosophila retroelement: evidence that gypsy is an infectious retrovirus. Genes Dev 1994;8:2046-2057.

6. Wright DA, Voytas DF. Athila4 of Arabidopsis and Calypso of soybean define a lineage of endogenous plant retroviruses. Genome Res 2002:12:122-131.

7. Pantazidis A, Labrador M, Fontdevila A. The retrotransposon Osvaldo from Drosophila buzzatii displays all structural features of a functional retrovirus. Mol Biol Evol 1999;16:909-921. 